\title{
"A Thousand Sages have but One Mind": The Forging of a Joint Chinese-Muslim Identity
}

\author{
Alexander Wain*
}

Malaysian Prime Minister Dato' Sri Najib Tun Abdul Razak's recent six-day trip to China revives a long tradition of Malay-Chinese co-operation stretching all the way back to the Melaka Sultanate. During the early fifteenth century, three of Melaka's Sultans travelled to China in person, where they vied with other nations to forge a special relationship with the Middle Kingdom. As a result, Melaka became China's closest ally, ultimately acting as a base for all Chinese activity in the Nusantara. It was largely because of this close co-operation and the immense wealth that it generated, that Melaka subsequently became the Nusantara's first great Islamic power, able to disseminate Islam throughout the region.

What may be less obvious to many, however, is that the Prime Minister's recent overtures also mark the continuation of a longstanding and mutually beneficial relationship between Islam and China. Although largely forgotten today, this relationship began during the very earliest days of Islam and, from the point of its inception, was facilitated by a recognition of shared values - that Muslim and Chinese culture shared a common core that, if properly appreciated, could help forge a lasting bond between the two civilisations.

Thus, according to Chinese Muslim (or Huihui) tradition, China's first Muslim community was established in 651 by the Prophet Muhammad's maternal uncle, Sa'd ibn Abi Waqqas. According to the Huihui, the Emperor Gaozong (r.649683) had a dream in which a turbaned man chased a devil around the palace. Gaozong's Interpreter of Dreams construed this devil as an ill-omen, but stated that "the turbaned man is a Huihui from the west. In Arabia is a Huihui king of great virtue. A great sage is born, with favourable omens." To avoid the illfortune portended by the devil, Gaozong therefore despatched an ambassador to Arabia to ask this great sage for help.

Although the Chinese ambassador naturally arrived in Arabia long after the Prophet's death in 632, he was nonetheless hospitably received by the Caliph 'Uthman, who responded to the Emperor's request by dispatching a delegation of sahabah headed by Sa'd ibn Abi Waqqas. After arriving in China, Sa'd met with Gaozong, who immediately became impressed with Islam; he felt that its teachings embodied the same principles as Confucianism, including loyalty to the sovereign, filial piety and brotherly love. Although ultimately declining to convert (he felt praying five times a day was too restrictive), as a mark of respect 
he allowed Sa'd to build China's first mosque - the still-extant Huaisheng mosque in Guangzhou.

Whatever the truth behind this tradition, by the eighth century China hosted a considerable Muslim population. As early as 748, large Muslim mercantile settlements had been established in Hainan and Guangzhou. By the Ming Dynasty (1368-1644), these had spread throughout China; augmented by centuries of trade and migration (especially from Central Asia), Muslims spread to every major Chinese city. In some instances, the most important Huihui families were centuries-long residents of China. Moreover, and just like Gaozong, they had noticed a set of commonalities between Islam and Confucianism.

The first indications of this awareness emerged during the mid-ninth century, when Muslims began to sit China's Imperial Examinations. These examinations required extensive study of the Confucian classics and, in 847, an Arab bearing the Chinese name Li Yanshong passed them with the highest degree, the jinshi. A feat achieved by few, Li's contemporaries attributed his success to his love of Chinese culture. Very soon, however, he was followed by many others. The prominent Muslim Ma family, for example, which first arrived in China in 968, produced its first degree holder in 1000. By the nineteenth century, thirty-one generations of this family had produced forty-four degree holders, thereby demonstrating its commitment to pursuing Confucian learning while also being actively Muslim.

This trend attained its clearest expression, however, in the seventeenthto eighteenth-century Muslim scholar, Liu Zhi. Trained in both traditional Chinese and Islamic thought, Liu Zhi considered Confucianism and Islam to be expressions of the same universal truth; delving into deep theological matters, he sought to highlight the numerous parallels between Islamic and Confucian teachings. These he attributed to a common source: using the Chinese word sheng (sage) to describe both the Prophet and Confucius, he argued that the latter had been a bearer of din al-fitra, or the 'natural religion' enshrined in the messages of the prophets before Muhammad. Liu Zhi argued that Confucius had been a bearer of this divine inspiration; although his message was subsequently distorted by later generations, Liu Zhi believed its core still preserved this fundamental, Islamic truth.

On this basis, and like other Huihui, Liu Zhi attempted a rapprochement between Chinese and Islamic civilisations. Neither did his attempts go unnoticed: his biography of the Prophet was honoured with a preface by the non-Muslim Vice-Minister of the Board of Ritual, who wrote: "The ancient Confucian doctrine has been undermined at different times by Buddhists and Taoists...now, however, in this book of Liu Zhi we see once more the way of the ancient sages...Thus, although this book explains Islam, in truth it illuminates our Confucianism." 
Against this backdrop, Malaysia's recent efforts to forge a closer relationship with China constitute a continuation of a long and proud Muslim tradition. Throughout their history, the Huihui demonstrated a willingness to use the commonalities between Islam and traditional Chinese culture to help bridge the two civilisations. In this context, a fourteenth-century inscription from a mosque in Sianfu cites a Chinese proverb: "A thousand sages have but one mind, and through ten thousand ages only one truth holds." As China once again comes to the fore as a world power, and at a time when declining Western nations are increasingly gripped by fervent nationalism and anti-Muslim rhetoric, Muslims should once again appeal to this "one truth" as a means of forging a new bond with China. Perhaps the Malaysian government's recent efforts will constitute a first step in that direction.

* Alexander Wain obtained his DPhil $(\mathrm{PhD})$ from the University of Oxford in 2015. A specialist in the history of Islam in Southeast Asia and China, his DPhil research focused on the possible role of Chinese Muslims in the conversion of the Nusantara (Maritime Southeast Asia) between the thirteenth and sixteenth centuries. Currently, he is Research Fellow at the International Institute of Advanced Islamic Studies (IAIS) Malaysia. At IAIS, Alexander is working on a critical outline of the Chinese Islamic philosophical school known as the Hān Kitāb. Drawing attention to the school's broad intellectual framework - in particular, its willingness to utilise both Islamic and non-Islamic texts, to marry Islamic and Neo-Confucian thought - Alexander aims to assess whether the Hān Kitāb's inherent inclusivity can contribute towards the principles of reform (ișlāh) and moderation (wasatiyyah) in modern-day Islam. Email: alex@iais.org.my. 